\title{
Towards a Kierkegaardian Retreating of the Political
}

\author{
Karlsen, Mads Peter
}

Document Version

Final published version

Published in:

Kierkegaard Studies Yearbook

DOI:

10.1515/kierke-2019-0015

Publication date:

2019

License

Unspecified

Citation for published version (APA):

Karlsen, M. P. (2019). Towards a Kierkegaardian Retreating of the Political. Kierkegaard Studies Yearbook, 24(1), 375-392. https://doi.org/10.1515/kierke-2019-0015

Link to publication in CBS Research Portal

\section{General rights}

Copyright and moral rights for the publications made accessible in the public portal are retained by the authors and/or other copyright owners and it is a condition of accessing publications that users recognise and abide by the legal requirements associated with these rights.

Take down policy

If you believe that this document breaches copyright please contact us (research.lib@cbs.dk) providing details, and we will remove access to the work immediately and investigate your claim. 


\section{Towards a Kierkegaardian Retreating of the Political}

"The 'Neighbor' is the absolutely true expression for human equality."1

Abstract: The first section of this paper argues that we can find in Kierkegaard an idea of equality, epitomized in the notion of "the neighbor" presented in Works of Love, which is highly relevant for, among other things, a critical engagement with today's "identity politics." The second section argues that Kierkegaard's idea of equality is a religious-existential task, but also a task concerning our relationship with other human beings. The third section demonstrates how this idea of equality is evinced in the notion of "the neighbor." The last section offers some reflections on how we might begin to rethink the political based on this idea of equality.

\section{Introduction: Kierkegaard and Politics?}

Kierkegaard and politics is perhaps not the most obvious and certainly not the most uncomplicated topic to engage in. I will begin by trying to explain very briefly in three points why I think this is the case. First of all, one might ask whether putting "Kierkegaard" and "politics" in the same sentence is even justifiable? After all, have not many commentators over the years pointed out that Kierkegaard's work stands out precisely for its striking lack of interest in political and social matters ${ }^{2}$ Kierkegaard himself notes on several occasions that he does not understand politics, and that it is not his business. ${ }^{3}$ Moreover, in certain passages of both his published works and his journals, it is quite obvious that he is not just indifferent, but even expresses a rather hostile attitude towards politics. In his journals he fiercely pits politics and Christianity against each other when, for example, he directly states: "If you want to be a Xn

I would like to thank Cathrine Bjørnholt Michaelsen for her useful comments in the preparation of the final version of this paper.

1 SKS 16, 91 / PV, 11.

2 E.g., Jørgen K. Bukdahl, "Forkundskaber for eksistensen," in his Frihed og frigørelse. Filosofi Teologi Kulturdebat 1956-1979, Copenhagen: Forlaget Aros 1980, p. 93.

3 E. g., SKS 28, 394 / LD, 255; SKS 28, 400 / LD, 261; SKS 28, 392 / LD, 253. 
[a Christian], then first and foremost forget all about politics." ${ }^{4}$ Indirectly, he expresses this opposition between politics and Christianity through a juxtaposition of what appear to be absolute oppositions, such as the profane versus the Christian, the crowd versus the single individual, the outward versus the inward, and temporality versus eternity. ${ }^{5}$

Therefore, and this is my second point, it is somewhat surprising thatdespite this hostility and self-proclaimed ignorance of politics-we know from Kierkegaard's journals that he followed the political events of his day quite closely, often commenting on them in detail. ${ }^{6}$ For the most part the political views expressed in his journals are at best reactionary and conservative, if not downright authoritarian, which only makes it harder to argue that these views have anything more than historical relevance or that they are of any contemporary relevance. ${ }^{7}$ In contrast to the somewhat hasty opinions jotted down in his journals, Kierkegaard notably also published a lengthy analysis of his own present-day, namely Two Ages: A Literary Review, in which he presents a more complex and nuanced characterization of the social and political situation while also providing a penetrating diagnosis of modernity. ${ }^{8}$

To make things even more complicated, one could argue, and it has been argued quite convincingly, that Kierkegaard's understanding of Christianity undergoes a significant transformation towards the end of his life, a transformation perhaps most clearly manifested in his uncompromising campaign against the established Danish church (the Church Struggle), and that this

4 SKS 21, 126, NB7:94 / KJN 5, 131.

5 E.g., SKS 16, 85-104 / PV, 105-122; SKS 9, 63-89 / WL, 61-90. How we understand these apparently absolutely opposed concepts is crucial (see, e.g., Bukdahl, "Forkundskaber for eksistensen,” p. 95, and Arne Grøn, Subjektivitet og negativitet: Kierkegaard, Copenhagen: Gyldendal 1997).

6 Peter Tudvad, "Søren Kierkegaard-Gud, konge og fædreland," Kritisk Forum for Praktisk Teologi, vol. 84, 2001, pp. 62-68.

7 An evident example of Kierkegaard's political conservatism could be his comment in 1848 on the precepts of a democratic government: “Of all tyrannies a people's government is the most excruciating, the most spiritless, unconditionally the downfall of everything great and sublime...A people's government is the true picture of hell" (SKS 27, 485, Papir 405 / JP 4, 4144). However, the question of the precise character of Kierkegaard's conservatism is obviously a more complex issue than this quote suggests. For an account of this issue, see Kresten Nordentoft, Søren Kierkegaard. Bidrag til kritikken af den borgerlige selvoptagethed, Copenhagen: Dansk Universitets Presse 1977, pp. 69-85.

8 For an analysis of Kierkegaard's political views in this text, see Kresten Nordentoft, "Hvad siger Brand-Majoren?”-Kierkegaards opgør med sin samtid, Copenhagen: GEC Gad 1973, pp. 25-66. 
transformation thus implies a radical change in how he views the relationship between the message of Christianity and the world's social and political affairs. ${ }^{9}$

In spite of-or perhaps precisely because of-the complexity and ambiguity of Kierkegaard and politics, one only has to glance at the most recent research literature to realize just how appropriate and timely a topic it has become. In the last five years alone, four books have been published on the subject: two monographs, respectively titled Kierkegaard's Indirect Politics: Interludes with Lukács, Schmitt, Benjamin and Adorno (2014), and Kierkegaard on Politics (2014); an anthology, Kierkegaard and Political Theory: Religion, Aesthetics, Politics and the Intervention of the Single Individual (2014), also published in 2014; and another anthology, Kierkegaard and Political Theology, published in 2018. ${ }^{10}$

To simplify matters a bit, I think that all the contributions in these four books have two basic approaches to the topic of "Kierkegaard and Politics." One approach focuses primarily on Kierkegaard's own conceptions of politics, while the other focuses on the potential of Kierkegaard's thought, as it is more broadly understood, in contemporary debates about and reflections on politics.

My approach to Kierkegaard and politics here will generally follow the latter approach. The following is thus neither an outline of Kierkegaard's politics nor an attempt to elaborate a political theory or a specific political program inspired

9 Nordentoft, “Hvad siger Brand-Majoren?”-Kierkegaards opgør med sin samtid, pp. 160-260. 10 Bartholomew Ryan, Kierkegaard's Indirect Politics: Interludes with Lukács, Schmitt, Benjamin and Adorno, Amsterdam and New York: Rodopi 2014. Barry Stocker, Kierkegaard on Politics, Basingstoke: Palgrave Macmillan 2014); Kierkegaard and Political Theory: Religion, Aesthetics, Politics and the Intervention of the Single Individual, ed. by Armen Avanessian and Sophie Wennerscheid, Copenhagen: Museum Tusculanum 2014; Kierkegaard and Political Theology, ed. by Roberto Sirvent and Silas Morgan, Eugene, OR: Wipf and Stock 2018. There is, of course, a much more extensive literature on the topic of Kierkegaard and politics. Some of the most noteworthy contributions are: A. Egelund Møller, Søren Kierkegaard om politik, Copenhagen: Forlaget Strand 1975; Kresten Nordentoft, Bidrag til kritikken af den borgerlige selvoptagethed; Gregor Malantschuk, Den kontroversielle Kierkegaard, Copenhagen: forlaget Vinten 1977; Bruce H. Kirmmse, Kierkegaard's Politics: The Social Thought of Søren Kierkegaard in Its Historical Context, Berkeley: University of California 1980; Hermann Deuser, Sören Kierkegaard. Die paradoxe Dialektik des politischen Christen: Voraussetzungen bei Hegel, Mainz and Munich: Matthias-Grünewald-Verlag 1974; and more recently: Kierkegaard: The Self in Society, ed. by George Pattison and Steven Shakespeare, London: Palgrave Macmillan 1998; Foundations of Kierkegaard's Vision of Community, ed. by George B. Connell and Stephen Evans, Atlantic Highlands: Humanities Press 1992. Kierkegaard's Influence on Social-Political Thought, ed. by Jon Stewart, Farnham and Burlington: Ashgate 2011 (Kierkegaard Research: Sources, Reception and Resources, vol. 14). 
by Kierkegaard. Rather, the aim of the paper is more modestly to indicate how Kierkegaard's idea of equality offers a fruitful starting point for thinking about what the political could mean today. ${ }^{11}$ The focus of the paper on Kierkegaard's idea of equality is partly inspired the French philosopher Alain Badiou (to whom I will return in the last section of the paper) who has on several occasions emphasized "equality" as the crucial concept for a contemporary philosophical thought on politics. ${ }^{12}$ But, Badiou also cautions about the major difficulty

11 My differentiation between politics (as a political program), political theory and the political, as well as my understanding of the latter term, draws to a certain extent on Philippe LacoueLabarthe and Jean-Luc Nancy's distinction between la politique (politics) and le politique (the political). This distinction plays an important role in the joint work they did on the "retreating of the political" at the Centre de recherches philosophiques sur le politique in the early 1980s. In the opening address to the center, which was later published as a part of a collection of papers presented there, Lacoue-Labarthe and Nancy delineate the distinction in the following way: "In speaking of the political we fully intend not to designate politics. The questioning about the political or about the essence of the political is, on the contrary, what for us must ultimately take stock of the political presupposition itself of philosophy...But this determination does not itself produce a political position... What remains to be thought by us, in other words, is not a new institution (or instruction) of politics by thought, but the political institution of socalled Western thought" (Philippe Lacoue-Labarthe and Jean-Luc Nancy, Retreating the Political, trans. by Simon Sparks, London: Routledge 1997, p. 110). The question of the political is for Lacoue-Labarthe and Nancy first of all "the question of the 'social bond' not as a presupposition, and yet as impossible to deduce or to derive from any initial subjectivity" (ibid., p. 118). However, according to Lacoue-Labarthe and Nancy such a philosophical questioning of the political, and the questioning of the philosophical about the political, has been withdrawn or retreated from our contemporary situation and replaced by an obviousness of the political, by the notion that "everything is political" (ibid., p. 111). It is worth noting that the French expression retrait (retreat) is used here by Lacoue-Labarthe and Nancy to capture both this retreating and a re-treatment of the political (to which their work aim), and that the latter involves a retreatment in the sense of a step back from the current obviousness (retreating) of the political (cf. ibid.). For more on the concept of retreating, see ibid., pp. 138-140.

12 E. g. Alain Badiou, Conditions, trans. by Steven Corcoran, London: Continuum 2008, p. 172. It should be mentioned that Badiou presented two papers on the retreating of Marxism at the Centre de recherches philosophiques sur le politique in 1984, which were published a year later as a small book entitled Can Politics be Thought? In this book, and in some of his later works, Badiou adopts the distinction between la politique (politics) and le politique (the political), but uses it in a rather different manner than Lacoue-Labarthe and Nancy. While "the political" (le politique) is used by Badiou as a designation of contemporary political philosophy (exemplified by Hannah Arendt) and the politics of parliamentarism that it legitimatizes, he reserves the term "politics" (la politique) for the rare instances in which something happens (an event) that leads to a new collective organization-as for example the event of May 68 in Paris. Badiou's term for the philosophical reflection on this kind of politics is “metapolitics." See Alain Badiou, Metapolitics, trans. by Jason Barker, London: Verso 2005, pp. $26-57$. 
awaiting such an endeavor, namely the difficulty "in subtracting the philosophical concept of equality from the economism that saturates it."13 However, as see will see, Kierkegaard's idea of equality is precisely an idea that has been completely "subtracted" from our ordinary political, sociological and economical, or in Kierkegaard's wording "worldly," notions of equality. Thus, the very same feature which seems to block any attempt to convert Kierkegaard's idea of equality into a specific political program might on the other hand provide us with an important resource for rethinking, or in Lacoue-Labarthe and Nancy's terms "retreating," the political.

Due to this particular focus, questions about Kierkegaard's private political views, and to some extent about the political conclusions that Kierkegaard himself drew from his thinking, are basically put in brackets, not because I think these questions are of little interest or import, but merely because for the moment I will leave them for others to wrestle with.

\section{Kierkegaard's Idea of Equality}

This paper argues that we can find an idea of equality epitomized in the notion of "the neighbor" that Kierkegaard presents in Works of Love. Although founded on a certain theological anthropology, this notion is highly relevant if one wants to critically engage with the currently prevailing secular conception of politics as "identity politics," whether it comes in the guise of a multiculturalism urging us to respect a multiplicity of minorities or of a nationalism urging us to stand guard over our own particular cultural uniqueness. However, in more general terms what is at stake with this idea of equality is, as we shall see, the issue of how to think the relationships between identity and difference, sameness and otherness, universality and particularity, and the implications of this for our understanding of subjectivity, inter-subjectivity and social relations. ${ }^{14}$

13 Badiou, Conditions, p. 174, It is important to note that Badiou's concept of "subtraction" (soustraction) does not merely designate a negative gesture of (with)drawing (away) from, but also a positive gesture of re-drawing the field of politics by re-inscribing something new into it (cf. ibid., pp. 113-128). Thus, there is, as also indicated by Nancy, a certain similarity between the notion of "retreating" and Badiou's concept of "subtraction" (Jean-Luc Nancy, The Inoperative Community, trans. by Peter Connor, Lisa Garbus, Michael Holland, and Simona Sawhney, Minneapolis: University of Minnesota Press 1991, pp. xxxviii-xxxix; see also Jean-Luc Nancy, The Creation of the World or Globalization, trans. by François Raffoul, New York: SUNY Press 2007, p. 85).

14 To put it crudely, one could say that what distinguishes Kierkegaard's way of thinking this relationship from the manner in which it is conceptualized in most identity politics is that he 
That Kierkegaard has an idea of equality, and that this idea is a key element of his thinking is hardly a new insight. In an essay from 1956 Johannes Sløk argued that the radical ideological changes brought about by the Enlightenment and the French Revolution made the idea of equality a fundamental issue for Kierkegaard. ${ }^{15}$ Another Kierkegaard scholar to emphasize the importance of Kierkegaard's idea of equality is Jørgen K. Bukdahl, who also interprets the notion in greater detail. Thus, Bukdahl opens his article "Ethics and Epoch: On the Idea of Equality in Søren Kierkegaard” from 1965 by stressing: "In Kierkegaard the idea of equality is an unyielding premise." 16 According to Bukdahl, this idea of equality is "emptied of any possible specific content," ${ }^{17}$ which is exactly why it is so radical: what makes all human beings equal is not this or that property or quality, but solely the fact that every human being is confronted with the same existential task of becoming oneself-more precisely the task of becoming oneself in relation to God (i.e., to relate to oneself as a self-relation constituted by another). "This task is" in Bukdahl's words, "the universal [det almene], the humane [det humane], the absolute [det absolutte]." ${ }^{18}$ He goes on to state that for Kierkegaard this is a task that everyone "can and must deal with entirely on her own." ${ }^{19}$ Thus, all human beings are equal in being tasked with becoming the single individual that each one is, but for this very reason all humans are also absolutely different. As such, Kierkegaard's idea of equality remains consistent with his critique of a particular political (socialist) idea of social equality in his age. ${ }^{20}$

According to a specific interpretation of Kierkegaard, Bukdahl may be right in emphasizing the secluded character of this common human task of becoming

thinks of it, not in terms of a binary logic, but against the backdrop of the Christian notion of trinity.

15 Johannes Sløk, “Kierkegaard og Luther," Kierkegaardiana, vol. 2, 1957, p. 19. Even if it is not explicitly expressed, the idea of equality also plays a central role in Jørgen Bukdahl's 1961 book Soren Kierkegaard and the Common Man, trans. Bruce H. Kirmmse, Grand Rapids: William. B. Eerdmans Publishing 2001.

16 Jørgen K. Bukdahl, “Etik og epoke. Om lighedstanken hos Søren Kierkegaard,” in Om Søren Kierkegaard. Artikel i udvalg ved Jan Lindhardt, Copenhagen: C.A. Reitzels Boghandel 1981, p. 52 (my translation).

17 Ibid. (my translation).

18 Ibid., p. 53 (my translation).

19 Ibid., p. 54 (my translation).

20 On more than one occasion Kierkegaard explicitly opposes his own (Christian) idea of equality, more precisely human equality (Menneske-Lighed), with a contemporary political (socialist) idea of equality. See, e.g., SKS 16, 83-84 / PV, 103-104; SKS 9, 72-73 / WL, 71-72; SKS 20, 339, NB4:13 / KJN 4, 340. 
oneself, yet this also raises the question of how we are to understand this claim against the background of Kierkegaard's relational understanding of the self. ${ }^{21}$ What is more, even if one maintains Bukdahl's perspective, one still has to question whether Kierkegaard's idea of equality and his conclusions about its consequences change over the course of his authorship on precisely this point. ${ }^{22}$

I would argue that at least in Works of Love the task of becoming oneself is not something the single individual "can and must deal with entirely on her own."23 On the contrary, I would insist that one could argue that in this work Kierkegaard holds that it is precisely, and exclusively, in relationship to another human being, understood as one's "neighbor," that the singular individual, "can and must" become oneself, thus stressing a dialectical relation between subjectivity and inter-subjectivity. Or, as Kierkegaard expresses it in the beginning of Works of Love in a compact paraphrase of the commandment of neighbor love: "You shall love yourself in the same way as you love your neighbor when you love him as yourself." ${ }^{24}$ In short, Kierkegaard's idea of equality, seen as the common human task of becoming oneself, that is, the task of relating to oneself in the right way, is indeed the religious-existential task emphasized by Bukdahl, among others, but also a task that inevitably concerns our relationship to our fellow human beings, or in other words, an ethical and political task. ${ }^{25}$

I would also maintain that this emphasis on the interrelatedness of the right way of relating to oneself (the right self-love) and the right way of relating to the other (the right love of the other) is a necessary consequence of Kierkegaard's theology and theological anthropology in Works of Love, and, more precisely, a consequence of the fact that in this work Kierkegaard consistently conceives

21 For a thorough discussion of this issue, see Arne Grøn, Subjektivitet og negativitet: Kierkegaard, p. $233 \mathrm{f}$.

22 See Nordentoft, "Hvad siger Brand-Majoren?”-Kierkegaards opgør med sin samtid, p. 199. 23 For other contributions on the idea of equality and politics in Works of Love, see Natalia Marandiuc, "Equality: a Proposal Rooted in Kierkegaard's Theological Anthropology and Theology of Love," in Kierkegaard and Political Theology, ed. by Roberto Sirvent and Silas Morgan, pp. 94-104; Jennifer Elisa Veninga, "Loving the Ones we See: Kierkegaard's Neighbor-Love and the Politics of Pluralism," in ibid., pp. 105-126; Peter George, "Something Anti-social about Works of Love," in Kierkegaard: The Self in Society, ed. by George Pattison and Steven Shakespeare, pp. 70-81; Martin Andic, "Is Love of Neighbour the Love of an Individual?," in ibid., pp. 112-124.

24 SKS 9, 30 / WL, 23.

25 Let me just note in passing that while Bukdahl also uses the term "ethics," he uses it, not as referring to issues concerning interpersonal relations, but, as he himself stresses, precisely as a designation for the existential task with which we are faced entirely on our own: "By 'ethics' is meant: with regard to the aforementioned existential task.” (Bukdahl, "Etik og epoke,” p. 53, my translation.) 
of God as love and man as created in God's image. In a passage in the section entitled "First Series II. C: You Shall Love the Neighbor" Kierkegaard formulates it thus: "Just as Christianity's joyful message is contained in the doctrine of humanity's inherent kinship with God, so is Christianity's task humanity's likeness to God. But God is Love: and therefore we can be like God only in loving, just as we also, according to the words of the apostle, can only be God's coworkers-in love." ${ }^{26}$ He goes on to clarify the specific character of the loving in which human beings can resemble God, stating that: "Insofar as you love the beloved, you are not like God, because for God there is no preference...Insofar as you love your friend, you are not like God, because for God there is no distinction. But when you love the neighbor, then you are like God."27 To this should be added that in Kierkegaard's reading "the neighbor" designates not only the other person but always also oneself, which is to say that both the other and the I are the neighbor. ${ }^{28}$

Against this background the common human task of becoming oneself-that is, of relating to oneself in the right way-is a matter of relating to oneself as the neighbor, which entails loving oneself in the right way. However, loving oneself in the right way is only possible by relating to another human being in the right way, namely as the neighbor, which entails loving the other in the right way. In Kierkegaard's words: "To love yourself in the right way and to love the neighbor correspond perfectly to one another; fundamentally they are one and the same thing."29 Moreover, the only way to relate to oneself as the neighbor-in relating to the other as the neighbor-is by relating to God, that is, by loving God (loving love). As Kierkegaard puts it: "Only by loving God above all else can one love the neighbor in the other human being." ${ }^{30}$ For Kierkegaard the right self-relation and the right relation with the other person are mediated by the relation with God, "God is the middle term," which is the relation by which every human being is the neighbor, the relation by which every human being realizes her humanity, and thus her likeness to God. However, one should also note that Kierkegaard thinks of these three relationships as interrelated, and the interrelation between them as dialectical in the sense that while a human being can only love herself and the other as the neighbor by loving God, the opposite is also true-a human being can only love God by loving herself and the other as the neighbor.

26 SKS 9, 69-70 / WL, 62-63.

27 SKS 9, 70 / WL, 63.

28 See, for instance, Kierkegaard's interpretation of the story of the good Samaritan, see SKS 9, $29-30 / W L, 22$.

29 SKS 9, 30 / WL, 22.

30 SKS 9, 64 / WL, 58. 
To sum up, one could say that with the notion of the neighbor Kierkegaard designates at once the common "humanity" of all human beings-in Danish Menneskelighed, which means both the likeness and equality (Menneske-lighed) of all human beings (an ambiguity that Kierkegaard frequently plays on in Works of Love)-and the common likeness, but not equality, of all human beings with God, for while human beings can love, only God is love. So, what precisely does Kierkegaard mean by this notion of the neighbor that lies at the heart of his idea of equality?

\section{Kierkegaard's Conception of the Neighbor}

As the italicization of the word "Neighbor" in the title of section II. B. in the second chapter of the first part of Works of Love suggests, this is the section where Kierkegaard discusses the notion of the neighbor. However, he has previously given the term significant consideration on several occasions. In a central passage in Section II. A. he writes:

\footnotetext{
Who, then, is one's neighbor? The word is obviously derived from "nearest" thus the neighbor is the person who is nearer to you than anyone else, yet not in the sense of preferential love, since to love someone who in the sense of preferential love is nearer than anyone else is self-love....The neighbor, then, is nearer to you than anyone else. But is he also nearer to you than you are to yourself? No, that he is not, but he is just as near, or he ought to be just as near to you. The concept "neighbor" is actually the redoubling of your own self; "the neighbor" is what thinkers call "the other," that by which the selfishness in self-love is to be tested. ${ }^{31}$
}

It is worth noting the neighbor's ambiguous character of nearness and otherness clearly stated in this quotation. The neighbor is, on the one hand, "nearer to you than anyone else" and, on the other hand, "what the thinkers call "the other." Kierkegaard further elaborates on these statements concerning the simultaneous nearness and otherness of the neighbor. First, he states that the nearness he has in mind between an individual and her neighbor is not to be understood as a nearness "in the sense of preferential love," as the nearness we feel for the other person in preferential love is an expression of self-love and thus, in fact, a nearness to ourselves. Put differently, in the case of preferential love the preferred person (the beloved or the friend) is near to us because we can identify with her and see ourselves in her-in short, because we find that she is similar to ourselves. In the case of preferential love the neighbor is near to us because she

31 SKS 9, 28-29 / WL, 21. 
is made into our mirror image, or in Kierkegaardian terms, into "another I." However, as Kierkegaard stresses a little later in the book: "Whether we speak of the first I or of the other I, we do not come one step closer to the neighbor, because the neighbor is the first you." ${ }^{32}$ If the neighbor is to be anything other than the I, it must be something other than another I, since the other I is the same as the first. The neighbor must be "the first you," as Kierkegaard notes. What does he mean by this? I will return to this question in a moment.

Second, Kierkegaard specifies the character of this "otherness" of the neighbor, which he accentuates with the term "the first you." According to Kierkegaard, the neighbor is not nearer to you than anyone else because of her similarity, which is to say that the nearness of the neighbor resides not in similarity, but in otherness. Nonetheless, Kierkegaard describes the nearnessin the non-preferential sense-of the neighbor as "the fundamental similarity" (Grund-ligheden): "To be sure, the wife and the Friend are not loved in the same way, nor the friend and the neighbor, but this is not an essential dissimilarity, because the fundamental similarity is implicit in the category 'neighbor."”33 But, this "fundamental similarity" (Grund-ligheden) does not lie in the fact that, when compared, all human beings have this or that property or quality in common, but that they are also something beyond the comparable, something else that makes them incomparable. This "fundamental similarity" is "implicit in the category "neighbor" and implies that the claim that "the neighbor is nearer to you than anyone else...yet not nearer to you than yourself...but exactly just as near," does not concern the same, but rather, as Kierkegaard underscores, precisely "what the thinkers call 'the other.' "34 It is not a particular identity, but a lack of identity (an otherness) that constitutes "the fundamental similarity" that the concept of the neighbor designates. This does not mean that every human being does not have a particular individual identity, which makes her different from any other person with a particular identity, but it means that no human being coincides without remainder with her identity. Every human being is also something else, something other, than a particular I. All human beings are characterized not only by their particular

32 SKS 9, 64 / WL, 57.

33 SKS 9, 143 / WL, 141. For a sound and original elaboration of Kierkegaard's concept of "Eiendommelighed" in relation to his idea of equality, see Kasper Lysemose, "Det næstekærlige fællesskab. Bemærkninger til kristendommens selv-dekonstruktion,” Religionsvidenskabeligt Tidsskrift, vol. 65, 2016, pp. 67-75.

34 SKS 9, 28-29 / WL, 21. 
qualities, but also-as Kierkegaard writes later in the book-by their singularity or "distinctiveness," in Danish "Eiendommelighed." 35

Thus, according to Kierkegaard, what Christianity aims at with the concept of the neighbor is certainly not to abolish the dissimilarity associated with our particular identities, "but it wants the dissimilarity to hang loosely on the individual." ${ }^{36}$ For as he explains: "when the dissimilarity hangs loosely in this way, then in each individual there continually glimmers that essential other, which is common to all, the eternal resemblance, the likeness." 37 Therefore, the issue is not that we need to respect dissimilarities and differences, as claimed in contemporary multiculturalism, or discriminate between them, as demanded by contemporary nationalism, but rather that we need to let the dissimilarity hang loosely so that we might glimpse the "essential other" of the neighbor. This does not mean, however, that the otherness of the neighbor can be known or recognized-on the contrary. The neighbor constitutes something unknowable in the fellow human being: "The neighbor is the utterly unrecognizable dissimilarity between persons or is the eternal equality before God." 38 To claim to recognize the otherness of the neighbor would indeed seem to be a way of avoiding confronting oneself, not merely with the other person as the neighbor, but also with oneself as the neighbor.

There is one last point I would like to highlight about the notion of "the other" that Kierkegaard introduces in his analysis of the concept of the neighbor. Implicit in the notion of the other is the question of what this other is other in relation to. The other indicated by the concept of the neighbor is not other in relation to the other person-to other human beings-because in the relationship with the other person, "the other" constitutes "the fundamental similarity" (that "which is common to all, the eternal resemblance, the likeness"). No, the other is rather other in relation to, not the other, but the third, that is, in Kierkegaard's terms God (love): "Christianity teaches that love is a relationship between: a human being-God-a human being, that is, that God is the middle term." 39 In short, in being the other to God, every human being dissimilar from each other is equal, or in Kierkegaard's words: "The neighbor is every person, since on the basis of dissimilarity he is not your neighbor, nor on the basis of similarity to you in your dissimilarity from other people. He is your neighbor on the basis of equality with you before God, but unconditionally every person has this

35 SKS 9, 257 / WL, 269.

36 SKS 9, 93 / WL, 88.

37 Ibid.

38 SKS 9, 74 / WL, 68.

39 SKS 9, 118 / WL, 107. 
equality and has it unconditionally." ${ }^{40}$ Against this background we can understand Kierkegaard's aforementioned claim that "the neighbor is the first you."

"The first you" is something that every human being is, just as every human being is an "I." There is a difference, though. A human being is an "I" by virtue of her relations with other human beings, yet it is not merely through her relations to other human beings that a human is "the first you." Rather, "the first you" is something that a human being is because her relations with other human beings are mediated through her relation to God. It is in relation to God-and more precisely in relation to the word of God, "You shall love..."that every human being is "the first you." This also explains what Kierkegaard means when he claims "the concept 'neighbor' is actually the redoubling of your own self." 41 When we understand ourselves as the neighbor we relate to ourselves not merely as an(other) "I" who stands in relation to another I, but we also relate to ourselves as a (first) "you" who stands in relation to God.

All of this also means that the idea of equality elaborated in Works of Love conceives of equality as meaning that all human beings are equal, not because of their relationship with each other, within which absolute equality, according to Kierkegaard, is impossible, but because of their singular and equal relation to God. Kierkegaard underscores this with a crucial distinction between worldly "equality [Lighed]" and Christian "equality [Ligelighed]" (in the English text translated respectively as similarity and equality):

\begin{abstract}
Well-intentioned worldliness remains piously, if you will, convinced that there must be one temporal condition, one earthly dissimilarity-found by means of calculations and surveys or in whatever other way-that is equality [Ligelighed]. If this condition became the only one for all people, then similarity [Lighed] would have been brought about. For one thing, however, this cannot be accomplished, and, for another, the similarity [Lighed] of all by having in common the same temporal dissimilarity is still by no means Christian equality [Ligelighed]. Worldly similarity [Lighed], if it were possible, is not Christian equality [Ligelighed]. Moreover, to bring about worldly similarity [Lighed] perfectly is an impossibility. ${ }^{42}$
\end{abstract}

The important point is that the idea of equality (Ligelighed) that Kierkegaard proposes in relation to the concept of the neighbor differs radically from our usual political notions of equality. Kierkegaard's idea of equality is based not on a more or less explicit claim that all humans have some kind of quality or

\footnotetext{
40 SKS 9, 67 / WL, 60.

41 SKS 9, 29 / WL, 21.

42 SKS 9, 78 / WL, 71-72.
} 
property in common, but rather on the claim that what all human beings have in common-due to their common relationship with God-is the absence of a common quality or property with which they can be fully identified. The consequence that Kierkegaard himself draws from this is, as also clearly indicated in the above quotation, to insist on an absolute dividing line between worldly politics, on the one hand, and Christian works of love, on the other hand. In short: The idea of equality (Ligelighed) epitomized in the concept of the neighbor should be separated (or "subtracted" or "retreated") from any concrete political aspirations to produce equality (Lighed). However, such a separation should not exclude us from considering the further implications of this idea of equality for how we might think about the political in new ways. Indeed, if we are to believe Alain Badiou, the only proper way to initiate a philosophical thinking of the political today is precisely by taking as your starting point a concept of equality that has been entirely "subtracted" from our ordinary political, sociological and economical notions of equality. ${ }^{43}$ In the next, and final, section I will try to give a few indications of what such a rethinking, or re-treating, of the political might imply.

\section{Closing Remarks}

I would like to conclude with a few general considerations on what conception of the political one might propose, taking Kierkegaard's idea of equality and the notion of the neighbor as a point of departure. I have three brief reflections on three political key concepts: equality, exchange (giving-receiving) and community.

First, I suggest that it could be helpful to begin a re-treating rethinking of the political based on Kierkegaard's notion of the neighbor by linking it to what

43 Badiou, Conditions, p. 174. Furthermore, as Ettore Rocca points out in an excellent reading of Works of Love, the conservative attitude expressed by Kierkegaard in the passage on worldly similarity and Christian equality quoted in the above contradicts central theoretical formulations in the book. Or as his puts it: "Why cannot the duty to love one's neighbor characterizing the Christian equality [ligelighed] entail that equality [lighed] or just lesser inequality also applies to the social life? Certainly it is impossible to realize worldly equality entirely, but this does not make the effort to achieve such equality less legitimate, which is true also from a Christian perspective. Nor is it possible to realize the Christian equality [ligelighed] in the world, but according to Kierkegaard this does not make any effort to realize it less legitimate, on the contrary." (Ettore Rocca, Kierkegaard, trans. by Ole Jorn, Copenhagen: Gyldendal 2016, pp. 236-237, my translation.) 
Badiou has termed an "axiomatic" understanding of equality. Let me quote a passage from Badiou's book Metapolitics from 1998:

It is very important to note that 'equality' signifies nothing objective here. It is not a question of the equality of social status, income, function and still less of the supposedly egalitarian dynamics of contracts or reforms. Equality is subjective...Such equality is by no means a social program. Moreover, it has nothing to do with the social. It is a political maxim, a prescription. Political equality is not what we desire or plan; it is that which we declare to be, here and now, in the heat of the moment, and not something that should be. ${ }^{44}$

I believe that in Works of Love the account Kierkegaard gives of his idea of equality (Ligelighed)-an account epitomized in the assertion that the neighbor is all human beings-nicely fits Badiou's axiomatic understanding of equality on the following three points. ${ }^{45}$

First, in Kierkegaard's exposition the claim that "the neighbor is all human beings, unconditionally every human being" is obviously not empirically verifiable, but is rather a matter of principle and, ultimately, of faith. Thus, in a Kierkegaardian conception of the political based on the notion of the neighbor the political would be grounded solely on the groundless subjective engagement, or what Badiou calls "fidelity," of whoever would be willing to commit themselves-without any proof or guarantees-to the principle that the neighbor is all human beings, unconditionally every human being.

Second, Kierkegaard emphasizes that the equality (Ligelighed) of neighbor love has nothing to do with bringing about "similarity among people in the world, to apportion to people, if possible equally, the conditions of temporality."46 Thus, a Kierkegaardian conception of the political focused on the notion of the neighbor would imply neither taking away nor celebrating social cultural or economic differences, which does not mean that it denies the existence of these differences. On the contrary, to quote Kierkegaard:

44 Badiou, Metapolitics, p. 98.

45 It should be emphasized that the claim here is not that Badiou's and Kierkegaard's conceptions of equality are the same, which would be a premature and problematic claim, but merely that Badiou's apprehension of equality as an axiom (rather than a program) can contribute to our understanding of Kierkegaard's idea of equality. The most important difference between Badiou's and Kierkegaard's ideas of equality is that while Badiou singles out the uniquely human capacity for thought as the basis of his concept of equality (cf. Badiou, Metapolitics, p. 97), Kierkegaard's idea of equality is, as we have seen, grounded precisely in the lack of any such common property or capacity, or, in other words, in the singularity (Eiendommelighed) of every human being (due to the latter's relation to God).

46 SKS 9, 75 / WL, 71. 
"There is plenty of dissimilarity in the world; there are dissimilarities everywhere in temporality-which, after all, is precisely the different, the multifarious." 47 However, the point is exactly that a Kierkegaardian conception of the political based on the notion of the neighbor must be "indifferent to differences," as Badiou puts it, ${ }^{48}$ or in Kierkegaard's words it must "let the dissimilarities be there; they do not matter either way."49 There are undeniably differences between human beings, but whether these be racial, social, cultural, economic, or other they cannot be the concern of a conception of the political that has the Kierkegaardian notion of the neighbor as its fulcrum.

Third, the point that the equality (Ligelighed) of being the neighbor does not need to be provided or produced, but is rather the starting point of politics, something to be assumed, becomes manifest, for instance, when in the beginning of the second part of Works of Love Kierkegaard states: "Love builds up by presupposing that love is present." 50 Thus, in a Kierkegaardian conception of the political equality (Ligelighed) is not the goal or objective of politics, something to be achieved in some uncertain future; rather, it is its precondition. If we think of the political in terms of Kierkegaard's notion of the neighbor, then equality (Ligelighed) cannot be turned into a political program, but must instead serve as a "maxim," "prescription” or an "axiom," to use Badiou's vocabulary. ${ }^{51}$ Thus, a Kierkegaardian conception of the political, whatever it might be in concreto, must be based on an axiom of equality (Ligelighed) in the sense sketched out above.

Next, a Kierkegaardian rethinking the political based on the concept of the neighbor would entail, as Kierkegaard puts it in the discourse on compassion, a notion of politics in which we "Can Give Nothing and Is Able to Do Nothing"nothing but love. ${ }^{52}$ So what does it mean to give nothing? Like Kierkegaard, JeanLuc Nancy argues in a lecture from 2001 that what the commandment of neighbor love demands us to give to the neighbor is not a particular thing, but precisely nothing, and he specifies this nothing as the impossibility of fully possessing oneself, so that what is given in love is the self, which we

47 SKS 9, 86 / WL, 81.

48 Alain Badiou, Ethics: An Essay on the Understanding of Evil, trans. by Peter Hallward, London: Verso 1998, p. 27.

49 SKS 9, 75 / WL, 69.

50 SKS 9, 225 / WL, 218. The basis of Kierkegaard's continuous claim that "love is present in the ground" of human existence (SKS 9, 210-212 / WL, 219-221) is, of course, the theological presupposition that human beings are created in the image of God and that God is love.

51 Cf. Badiou, Metapolitics, p. 99: "[E]quality is not an objective of action, it is its axiom." 52 SKS 9, 300-314 / WL, 315-330. 
ourselves do not possess. According to Nancy, Jacques Lacan expresses the same thought when he famously defined love as "to give what you don't have to someone who does not want it." ${ }^{33}$ By this he means to give nothing but your non-possession of yourself-in psychoanalytical terms, your lack or your castration-to the other. To give nothing, in this sense, would be an act of love that refrains from confirming our own as well as the other's identity, an act that breaks with the logic of identity and reciprocity that usually governs our social interactions.

Yet, love is not just giving, it is also receiving. Love is, as Kierkegaard describes it, a "need to love and be loved." ${ }^{4}$ Loving the other as your neighbor by giving her nothing, your non-possession of yourself, your lack, would also include being willing to receive nothing from the other, and not simply in the sense of accepting that you get nothing in exchange, not even a sign of gratitude, but in the sense of welcoming the other's non-possession of herself, her lack, her castration, and thus in a certain way receiving-through a sort of "double movement"-what you are yourself. Kierkegaard seems to have something like this in mind when in Works of Love (in the discourse entitled "Love Does Not Seek Its Own") he invokes a New Testament reference to stress that only "the person who loses his soul will gain it." 55 Prior to this statement Kierkegaard has explicated what it means that "love does not seek its own." 56 His claim is that this would entail there being no distinction between the possessive pronouns "mine" and "yours." Erasing this distinction, which definitively supports what is perhaps the ultimate logic of social interaction, that is, the principle of private property, is only possible precisely for "the self-denying love" that knows nothing "about an exchange that erotic love makes" or of "how to watch out whether like is now given for like so that the friendship

53 Jean-Luc Nancy, “Love and Community,” pp. 1-3 https://aphelis.net/wp-content/uploads/ 2014/09/NANCY_2001_Love_and_Community_URLs.pdf (December 14, 2018). Though Nancy does not mention Kierkegaard in this text, he does so elsewhere. For instance, in a chapter of his 2011 book L'Adoration where he, with reference to Works of Love, argues that "the love called 'Christian' is strictly speaking indissociable from equality. Kierkegaard puts it rigorously” (JeanLuc Nancy, Adoration: The Deconstruction of Christianity II, New York: Fordham University Press 2013, p. 59).

54 SKS 9, 148 / WL, 155.

55 SKS 9, 256 / WL, 268. Kierkegaard uses a similar expression when he in The Sickness unto Death describes how "you must go through the despair of the self to the self...[;] the self must be broken to in order to become itself" (SKS 11, 179 / SUD, 65).

56 SKS 9, 264 / WL, 265. 
can be maintained." 57 Eliminating the distinction between mine and yours would entail placing, not merely our possessions, but even our possession of ourselves in the hands of our neighbor, thereby precisely giving and receiving the (non-) possession of ourselves to and from each other.

Finally, if a Kierkegaardian conception of the political implies notion of community, perhaps a community of neighbors, then this is not-even if it is based on equality-a community in which we have everything in common, a community in which "mine and yours become ours," because according to Kierkegaard: "ours is for the community exactly the same as mine is for the solitary one;" that is, such a community is still a community based on property (and exchange). ${ }^{58}$ In other words: a community in which we have everything in common is still a community in which we have something in common, that is, a community based on a particular quality or a specific identity. A community of neighbors, however, cannot be a community defined by a particular identity or a specific quality. Rather, as I have stressed, the absence of a common identity or specific quality is precisely what those who belong to such a community have in common. Thus, the community of neighbors would be a community of those who have, not something, but nothing in common. ${ }^{59}$ Or, as Nancy formulates it in the aforementioned lecture: "I would say the community of love is a community living to share the absence of common being. Not the absence of being-in-common, but the absence of common being. There is no common property, and that is what we have to share." 60

Nancy's key example of the absence of common being, which is shared in a community of those who have nothing in common, is death. In short Nancy's claim is that it is due to the common yet singular death that parts us from ourselves as well as from each other, and which thus makes any communion impossible, that we are part of a community in which this impossibility can be shared (i.e. a community of love). ${ }^{61}$ Another way of putting it, which brings

57 SKS 9, 256 / WL, 269. For more on the issue of how the abolishment of the distinction between mine and yours subverts the right to private property, see Ettore Rocca, Kierkegaard, pp. 241-241.

58 SKS, 265 / WL, 266.

59 I am here paraphrasing the title of Alfonso Lingis' book The Community Of Those Who Have Nothing In Common, Indianapolis: Indiana University Press 1994.

60 Nancy, "Love and Community," p. 2. For an elaboration of this notion of a community of those who have nothing in common, see Jean-Luc Nancy, The Inoperative Community, and Maurice Blanchot, The Unavowable Community, trans. by Pierre Joris, Barrytown: Station Hill Press 1988. On neighbor love in Kierkegaard and community in Nancy, see Lysemose, "Det næstekærlige fællesskab,” pp. 57-77.

61 Nancy, The Inoperative Community, p. 15. 
us closer to a parallel thought expressed in Kierkegaard's up-building discourse "At a Graveside," would be to say that in (thinking on our own) death we are exposed to the (in)equality of having nothing in common. In death "we are alike because each one of us is exposed to the outside that we are for ourselves." ${ }^{62}$ Kierkegaard puts it this way: "No comparison is as earnest as the comparison of the one who, alone, compares himself with the equality of death. Alone, because that is indeed what the equality of death makes him when the grave is close..., alone out there where the multitudes of the dead do not form any kind of society." ${ }^{33}$ Yet, there is also a distinctive difference between Nancy and Kierkegaard here. For Nancy the (in)equality of death teaches us the impossibility of sharing a common being, the impossibility of any communion, but the (in)equality of death also teaches us that this impossibility is what we can share, and thus that it is the very possibility of community. For Kierkegaard, on the other hand, what the earnest thought of the (in)equality of death teaches us, or ought to teach us, is first and foremost "to seek before God the equality in which all are able to be equal." 64 This is the equality of being the neighbor that we are exposed to in the commandment of neighborlove.

62 Ibid., p. 33.

63 SKS 5, 458 / TD, 89 (translation modified).

64 Ibid. 